This item was submitted to Loughborough's Research Repository by the author.

Items in Figshare are protected by copyright, with all rights reserved, unless otherwise indicated.

\title{
Stabilization of fine gravels by net-spinning caddisfly larvae
}

PLEASE CITE THE PUBLISHED VERSION

http://dx.doi.org/10.1002/esp.1750

PUBLISHER

(c) John Wiley \& Sons, Ltd.

VERSION

SMUR (Submitted Manuscript Under Review)

LICENCE

CC BY-NC-ND 4.0

REPOSITORY RECORD

Johnson, Matthew F., lan Reid, Stephen P. Rice, and Paul J. Wood. 2019. "Stabilization of Fine Gravels by Net-spinning Caddisfly Larvae”. figshare. https://hdl.handle.net/2134/13027. 
This item was submitted to Loughborough's Institutional Repository (https://dspace.lboro.ac.uk/) by the author and is made available under the following Creative Commons Licence conditions.

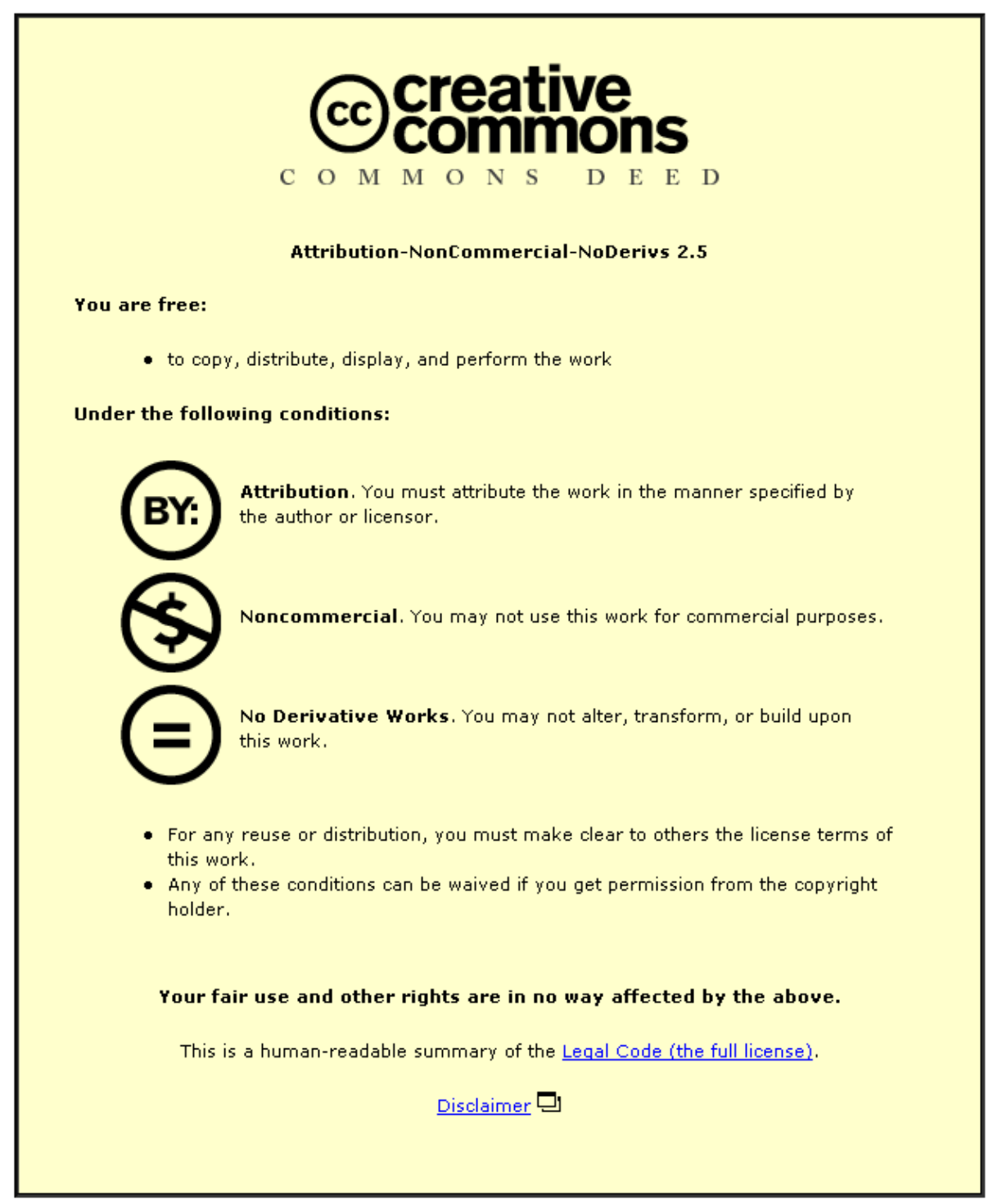

For the full text of this licence, please go to: http://creativecommons.org/licenses/by-nc-nd/2.5/ 
Title:

The influence of net-spinning caddisfly larvae on the incipient motion of fine gravels: an experimental field and laboratory flume investigation

Authors:

Johnson, Matthew F.

Reid, Ian

Rice, Stephen P. (s.rice@lboro.ac.uk)*

Wood, Paul J.

Department of Geography, Loughborough University, Loughborough, LE11 3TU, UK

* corresponding author

Submitted to:

Earth Surface Processes and Landforms, March 2008 


\section{Abstract}

We examined the impact of Hydropsychidae caddisfly larvae on the incipient motion of two sizes of narrowly graded fine-gravel (4-6 and 6-8 mm). This impact was assessed relative to the collective impact of other abiotic and biotic processes that are potentially important conditioning agents of fine-gravels. Trays of gravel were placed in the River Soar, Leicestershire, UK, where they were colonised to natural densities by caddisfly larvae. Identical trays that were surrounding by a $250 \mu \mathrm{m}$ mesh were also deployed, preventing colonisation but allowing field conditioning of sediments, including minor reworking of grains and biofilm development. After 21 days in the river, trays were removed to a laboratory flume where grain entrainment stresses were established. In addition to the colonised and conditioned treatments, critical shear stresses were measured for identical sediments that were not placed in the river (laboratory gravels). Gravels that were colonised by Hydropsychidae required significantly greater shear stresses for entrainment than conditioned trays $(p \leq 0.002)$, however, there was no significant difference between conditioned and laboratory gravels. This implies that the presence of caddisfly can be a more important influence on fine-gravel stability than some conditioning processes. Shields parameter was compared across treatments and across the two gravel size-fractions using two-way ANOVA. No significant differences or interactions were observed, indicating that 4-6 mm gravel was stabilised to a similar degree as $6-8 \mathrm{~mm}$ gravel by conditioning and colonisation processes. Our results extend earlier studies in two important ways: (1) entrainment stresses were established for fine gravels that were colonised at natural densities, under natural stream conditions and (2) the caddisfly effect was measured relative to both field-conditioned and unconditioned laboratory controls. The temporal and spatial 
distribution of silk-spinning caddisfly larvae suggests that they have the potential to influence fine-sediment mobility in many rivers, worldwide.

Key words: ecosystem engineering, Shields parameter, Hydropsychidae, entrainment threshold, biofilm. 


\section{Introduction}

Organisms that modify and help to structure their physical habitat are referred to as ecosystem engineers (Jones et al., 1994; Stallins, 2006). Many plants and animals engage in ecosystem engineering and their individual and cumulative activities can have substantial impacts on sediment fluxes and landform development (Viles, 1988; Butler, 1995; Dietrich \& Perron, 2006), as well as on wider ecosystem structure and functioning (Moore, 2006). In rivers, a variety of plants and animals are known to be ecosystem engineers. The growth of instream and riparian vegetation can stabilise stream banks and benthic sediments, dramatically changing local sedimentological and hydraulic conditions (Green, 2005; Cotton et al., 2006). Within productive lowland rivers, aquatic macrophytes (e.g., Ranunculus spp.) have been found to modify significantly instream hydraulic conditions, reducing flow velocity within individual stands and leading to fine sediment deposition of up to $0.085 \mathrm{~m}^{3} \mathrm{~m}^{-2}$ in a single month (Wharton et al., 2006). The creation of spawning redds by salmonid fish removes fine sediment from the surface layers of the substrate, changing the local bed material grain-size distribution (Kondolf et al., 1993; Moore et al., 2004) and, at popular spawning sites, redd construction can substantially affect vertical sediment sorting, armour development and bedload flux (Gottesfeld et al., 2004). The foraging activities of other fish species may have significant cumulative impacts on the presence of macrophyte and local substratum composition (Power, 1990; Flecker, 1996; Statzner et al., 2003b). Mammals such as beavers also affect river morphology by constructing dams that alter flow and sedimentation patterns (Gurnell, 1998) and beaver ponds are estimated to trap between $10^{8}$ and $10^{10} \mathrm{~m}^{3}$ of sediment in North America alone (Butler \& Malanson, 2005). In addition, the trampling of channel margins by domestic 
livestock, particularly cattle, reduces bank strength and is a well-known cause of channel widening (Trimble \& Mendel, 1995).

Despite their comparatively small size, aquatic macroinvertebrates also have significant impacts on their physical environment by removing fine sediments from interstitial spaces (Pringle et al., 1993; Zanetell \& Peckarsky, 1996; Parkyn et al., 1997; Statzner et al., 2003a), modifying local hydraulic conditions (Thomson et al., 2004) and increasing the porosity and permeability of bed sediments (Mermillod-Blondin et al., 2003; Nogoro et al., 2006). In addition, some silk-producing, caseless, caddisfly larvae can stabilise bed sediments in the 2-8 mm size range (Cardinale et al., 2004) by constructing silk nets for feeding galleries (Alstad, 1987a; 1987b; Statzner \& Bretschko, 1998; Edler \& Georgian, 2004; Brown et al., 2005) and retreats (Statzner et al., 1999). The silk binds fine sediment together thereby increasing critical entrainment stresses. This engineering activity benefits the individuals involved by providing stable feeding sites, but, potentially, it has ecological benefits for the wider community because patches of stable bed material can act as refugia from hydraulic disturbance (Winterbottom et al., 1991; Lancaster \& Hildrew, 1993; Lancaster, 2000). Moreover, the ecological engineering activities of these organisms may add to the complex set of interacting factors that are known to affect particle entrainment from non-cohesive river beds, including grain size, density and shape, particle protrusion and the geometric arrangement of surrounding grains (e.g. Fenton and Abbott, 1977; Komar and Li, 1986; Carling et al; 1992; Buffington \& Montgomery, 1997).

Experimental investigations using artificial channels ( $0.1 \mathrm{~m}$ wide, $0.1 \mathrm{~m}$ deep and $1.0 \mathrm{~m}$ long) have demonstrated that the presence of caddisfly larvae from the family Hydropsychidae can increase particle stability (Cardinale et al., 2004). In these experiments, caddisfly were seeded at particular densities onto clean gravels that were 
unaffected by other natural, in-stream, processes that might also reduce particle stability: for example, natural flow variations that organise bed materials into more or less stable configurations and the presence of natural biofilms and periphyton. Statzner et al. (1999) attempted to examine the influence of caddisfly on entrainment in natural settings, but interpretation of their results was complicated by flood disturbance during the experiment. Takao et al. (2007) found that filter-feeding caddisfly biomass was correlated to clast stability; however, this does not imply that these clasts had been engineered, because filterfeeding caddisfly are known to live preferentially in stable areas due to their sedentary life style.

\section{Aims}

To extend understanding of the role of silk-producing caddisflies (from the family Hydropsychidae) on particle entrainment, this study compares thresholds of incipient motion for colonised and river-conditioned but uncolonised sediments using combined field and laboratory flume experiments. In contrast to previous work, we examine the incipient motion of fine-gravel substrates that have been colonised to natural densities, without isolating the animals from those abiotic and biotic interactions inherent in field environments that may influence engineering potential (Moore, 2006; Statzner and Sagnes, 2008). We are able, therefore, to examine the caddisfly impact relative to the collective effects of some other ambient, abiotic and biotic processes that are potentially important conditioning agents of fine-gravel entrainment.

There is an expectation that coarse gravel entrainment is not affected by caddisfly silk because the influence of particle weight is thought to be over-riding as grain size increases. However, the lower grain-size limit of this effect is unknown. We examine, therefore, the 
entrainment of two size fractions of fine gravel (4-6 and 6-8 $\mathrm{mm}$ ) in order to evaluate whether caddisfly impact is grain size-dependent. Within our general aim of quantifying the degree to which silk producing caddisflies (Hydropsychidae) stabilise fine-gravel bed materials, we test the following specific hypotheses:

1. Fine-gravel patches colonised by Hydropsychidae larvae require higher shear stresses for entrainment than uncolonised gravels of the same size that are conditioned by natural, instream biotic and abiotic processes.

2. Fine-gravel patches not colonised by Hydropsychidae, but conditioned by natural biotic and abiotic processes, require higher shear stresses for entrainment than clean laboratory gravels of the same size.

3. As gravel size increases in a narrow range from 4 to $8 \mathrm{~mm}$, the relative differences between entrainment stresses for these three treatment groups declines due to the increasing importance of particle inertia.

\section{Methods}

\section{Overview}

To test these hypotheses, a combined field and flume investigation has been undertaken. Trays of narrowly graded sediments $(4-6 \mathrm{~mm}$ and 6-8 $\mathrm{mm})$ were placed in a local river where caddisfly larvae from the family Hydropsychidae are abundant. Some trays were left open to allow colonisation (dubbed “colonisation” trays) and an equal number were 
covered with $250 \mu \mathrm{m}$ mesh to prevent colonisation but allow other influences and processes (“conditioned” trays). After 21 days, these trays were carefully removed from the field site and placed in a laboratory flume where the shear stress required to mobilise the sediment in each tray was measured through assessment of the near-bed flow velocity profile. In the field, both sets of trays were subject to several processes that might condition sediment entrainment (in addition to the caddisfly effect in the case of the colonised trays), including biofilm development and small-scale sediment reworking under low-flow conditions. To assess the collective role of these conditioning factors, entrainment stresses were also established for a third set of "laboratory" trays that contained the same sediment mixtures but that were not placed in the river. Comparisons of the entrainment stresses for the colonisation versus conditioned and conditioned versus laboratory trays provide tests of hypotheses 1 and 2. Comparison of these results for the 4-6 and 6-8 mm gravels provides a test for hypothesis 3. A fourth set of open, “enumeration” trays was placed in the river but not subjected to entrainment measurements. These provided information about colonisation densities of Hydropsychidae larvae and other benthic taxa and allowed qualitative evaluation of hydropsychid silk producing activity and other stream conditioning processes.

\section{Sediment test trays}

Twenty-four, rigid, moulded-plastic containers (0.19 m long, $0.14 \mathrm{~m}$ wide and $0.05 \mathrm{~m}$ deep) were filled with 4-6 mm gravel and twenty-four of the same 'trays' were filled with 6-8 mm gravel. For each grain-size fraction, six replicates were used for each experimental treatment (colonisation, conditioned, laboratory) and six additional trays were used for enumeration. All sides of all trays were perforated with $4 \mathrm{~mm}$ diameter holes to allow 
colonisation laterally through the substrate as well as across the surface via drifting or crawling. The $250 \mu \mathrm{m}$ mesh netting used to exclude Hydropsychidae larvae and other macroinvertebrates allowed colonisation by smaller invertebrates (meiofauna) but, because of their size and life-style, they are not thought to be a significant factor in the stability of gravels in this study.

\section{Field Procedure}

The colonisation, conditioned and enumeration trays were deployed on a large riffle in the River Soar, Leicestershire UK ( $\left.1^{\circ} 11.0^{\prime} \mathrm{W}, 5^{\circ}{ }^{\circ} 46.8^{\prime} \mathrm{N}\right)$ for 21 days in July -August 2006. This period provided sufficient time for colonisation and is consistent with other investigations that consider substrate colonisation by benthic macroinvertebrates (Mackey, 1992; Cardinale et al., 2002). The riffle has a relatively uniform geomorphic and hydraulic environment and supports high densities of several hydropsychid caddisfly larvae species (Hydropsyche angustipennis [Curtis, 1834], H. contubernalis [McLachlan, 1865] and $H$. pellucidula [Curtis, 1834]). The River Soar is a gravel-bed channel with a well-developed alluvial floodplain and a meandering planform. Average channel width at the study site is approximately $15 \mathrm{~m}$ and mean water depth during the study was approximately $0.5 \mathrm{~m}$. The mean discharge at Pillings Lock, $3.5 \mathrm{~km}$ upstream and the closest gauging station to the field site, is $9.8 \mathrm{~m}^{3} \mathrm{~s}^{-1}$ and the $Q_{10}$ flow (that which is exceeded $10 \%$ of the time) is $22.0 \mathrm{~m}^{3}$ $\mathrm{s}^{-1}$. Thirty-six trays were introduced to the river over a ten-day period in July 2006. Deployment of trays was staggered so that entrainment measurements for a particular tray could be made in the flume on the same day that the tray was removed from the river. This was necessary to prevent the degradation of silk structures, biofilms and other biological 
materials. The total field deployment lasted 34 days and during that period there were no major flow events. The mean daily discharge at Pillings Lock was $3.9 \mathrm{~m}^{3} \mathrm{~s}^{-1}$, with daily averages ranging between 2.7 and 7.4 and a standard deviation for the period of $1.1 \mathrm{~m}^{3} \mathrm{~s}^{-1}$. Although tray deployment was staggered, trays were inserted in triples (colonisation, conditioned, enumeration) so that the small variations in flow did not bias one particular treatment.

Small rectangular slots were excavated in the bed with minimal disturbance, so that the trays could be placed in the river with their surface conformable with that of the local bed material surface (Figure 1). Trays were distributed throughout the riffle in such a way as to avoid disturbance when retrieving trays. When removing the trays from the river and transporting them back to the laboratory, great care was taken not to disturb the sediments. A large deflector was placed in the river upstream of the trays to block the flow and prevent fine material and invertebrates from being washed out of the trays as they were removed from the river. The rigidity of the trays meant that there was minimal disturbance as they were lifted out of the river and returned to the laboratory.

\section{Flume set-up and procedures}

A tilting laboratory flume was used to determine entrainment thresholds. The flume has a $10 \mathrm{~m}$ working section that is $0.3 \mathrm{~m}$ wide, with parallel, glass walls. Depth, velocity and energy slope are controlled by adjusting flume gradient, the elevation of the outflow weir and pump discharge. Through the lower-central length of the flume, a false bed was constructed to a height of $0.05 \mathrm{~m}$ and this incorporated a cavity that allowed snug insertion 
of the experimental trays. A ramp, $2.8 \mathrm{~m}$ upstream from the test site, linked the flume bed to the false bed over a distance of $0.3 \mathrm{~m}$. To reproduce natural, near-bed flow conditions and ensure a fully developed boundary-layer, roughness was added to the flume bed, including the raised portion, in the form of rigid panels to which a complete, uniform covering of gravel particles $(8-10 \mathrm{~mm})$ was fixed using adhesive. Once in place, the lip of each experimental tray was flush with the rough surface on the false bed. The cavity accommodating the test trays was positioned $5.48 \mathrm{~m}$ down the flume from the inlet. Depth and velocity measurements in the test section showed the flow to be uniform and steady.

An initial set of observations, guided by prior competence calculations, was used to establish a flume set-up that generated shear stresses which were marginally insufficient to entrain clean gravel particles of either size fraction (slope $=0.001$, water depth $=0.07 \mathrm{~m}$, mean velocity $=0.43 \mathrm{~m} \mathrm{~s}^{-1}$ ). By gradually increasing pump discharge, without changing the gradient and while maintaining constant water depth through adjustment of the tail weir, higher shear stresses eventually capable of entraining the test gravels were obtained.

Some of the colonised trays containing 4-6 mm gravel had experienced small amounts of scour during field deployment. This meant that when placed in the flume, the sediment surface in these trays was below the level of the false bed. This discordance could have generated hydraulic differences sufficient to affect the entrainment stresses that were measured. To assess this, we measured entrainment stresses for a fourth set of six trays containing clean 4-6 mm gravels which were first scoured in the flume to a depth that mimicked the observed field scour (up to $0.01 \mathrm{~m}$ ). Comparison between the entrainment thresholds for these scoured trays and the standard laboratory trays provided a test of whether scour-generated discordance is likely to have affected the entrainment stresses measured for those colonised trays that had experienced scour. 


\section{Entrainment measurements and analysis}

For each flume run, a single tray (colonised, conditioned, laboratory or scoured) was carefully fitted into the cavity in the raised bed. After 15 minutes of low flow, pump discharge was increased in stepped increments whilst maintaining a constant water depth and slope, to give successive flow stages. The mean velocity increased from $0.43 \mathrm{~m} \mathrm{~s}^{-1}$ to $0.84 \mathrm{~m} \mathrm{~s}^{-1}$ over 13 flow stages; each flow stage was maintained for 300 seconds. Preliminary observations had indicated that initiation of grain movement was most likely to occur within this period.

Bed material entrainment is not easily correlated with gross hydraulic properties due to the heterogeneity of gravelly bed materials and the spatial and temporal variability of hydraulic forces impinging on the bed (Buffin-Bélanger et al., 2006). Therefore, a single threshold of motion, although practicably desirable, is not easily determined or appropriate and it has been suggested that multiple thresholds (Wilcock \& McArdell, 1993) or no specific threshold (Paintal, 1971; Newson, 1992) may be more realistic. The difficulty of identifying incipient motion is greater for sediment containing a range of grain sizes. This is the reason we have used two narrowly-graded grain-size fractions in our experiments.

In accordance with a large body of previous work on entrainment, we have utilised a pragmatic definition of entrainment threshold based on visual observation (Wilcock, 1988; Buffington and Montgomery, 1997). As flow strength was increased, entrainment began with small, occasional movements of isolated grains. However, in all our experimental runs, a step-change was clearly observed as flow was increased, whereby this occasional 
single-grain movement was replaced by general movement of the majority of surface grains, mimicking direct observations made in the field, where the bed has been water-lain and naturally conditioned (Garcia et al, 2007). We used the start of this latter, widespread movement of grains as our definition of the entrainment threshold. Like many earlier studies, this direct, visual method does not depend on a formal flux criterion (Neill and Yalin, 1969; Wilcock, 1988). In order to ensure consistency of judgement, a single operator (MFJ) assigned all entrainment thresholds. Such a method is considered particularly appropriate when applied to discrete textural patches like those used in this study (Buffington \& Montgomery, 1997).

When the entrainment threshold was reached in each case, a detailed velocity profile was obtained $0.02 \mathrm{~m}$ upstream of the tray. A Nixon propeller flow meter (impeller diameter $=$ $10 \mathrm{~mm}$ ) was used to obtain mean streamwise velocity over 30 -second periods at $0.01 \mathrm{~m}$ depth increments throughout the flow depth. Once the measurements were completed, the flume was drained slowly and the tray was carefully removed and photographed.

The critical bed shear stress at incipient motion $\tau_{c i}$ for grain size $D_{i}$, was estimated from the observed velocity profiles according to the law of the wall as:

$$
\tau_{c i}=\rho v^{2}
$$

where $\rho$ is water density $\left(=1000 \mathrm{~kg} \mathrm{~m}^{-3}\right)$ and $v^{*}$ is shear velocity. Shear velocity was estimated from:

$$
v^{*}=c / b
$$


where $c=2.5$ and is the reciprocal of the von Karman constant for clear water flows, $\kappa=$ 0.41 , and the parameter $b$ is the slope of a linear least-squares regression of velocity $\left(\mathrm{m} \mathrm{s}^{-1}\right)$ on the logarithm of depth $(\mathrm{m})$ in the measured profile $\left(\mathrm{R}^{2}\right.$ values ranging from 0.919 0.993). To enable direct comparison of the stresses required to entrain $4-6 \mathrm{~mm}$ and 6-8 mm sediments, the dimensionless Shields parameter $\left(\theta_{c i}\right)$ was also calculated for each case as:

$$
\theta_{c i}=\tau_{c i} /\left(\rho_{s}-\rho\right) / g D_{i}
$$

where $\tau_{c i}$ is the shear stress at incipient motion for grain size $D_{i}, g$ is the acceleration due to gravity $\left(=9.81 \mathrm{~m} \mathrm{~s}^{-2}\right)$ and $\rho_{\mathrm{s}}$ is sediment density $\left(=2650 \mathrm{~kg} \mathrm{~m}^{-3}\right)$.

The entrainment thresholds relating to tray treatments were compared using paired t-tests (independent) and a two-way analysis of variance (ANOVA), with particle size (4-6 mm and 6-8 mm) and treatment (colonised, conditioned and laboratory) as the fixed factors.

\section{Enumeration Trays}

Upon removal from the field, trays intended to enumerate macroinvetebrates and silk structures were preserved in 70\% industrial methylated spirit (IMS) until analysis. Analysis involved detailed inspection and photography of the sediment surface for evidence of Hydropsychidae larvae silk structures. Subsequently, the trays were dissected and Hydropsychidae larvae counted and identified to species level. Other macroinvertebrate taxa present in the trays were recorded and enumerated. Grain-size distributions of the sediment that was recovered in the enumeration trays were obtained by standard sieving techniques. 


\section{Results}

\section{Macroinvertebrate colonisation and silk constructions}

The total abundance of macroinvertebrates recorded in each set of six enumeration trays ranged between 1240 and $4737 \mathrm{~m}^{-2}$ for the $4-6 \mathrm{~mm}$ gravel and 1842 and $3797 \mathrm{~m}^{-2}$ for the 6-8 mm gravel. Mean abundance values were not significantly different between the two grain sizes $(\mathrm{t}=-0.373, \mathrm{p}=0.724, \mathrm{n}=6)$. Hydropsychid caddisfly larvae and their silk constructions were recorded in all enumeration trays but were present in greater numbers in those with 6-8 mm gravel. Hydropsychidae larvae comprised 21\% (4-50\%) of the total macroinvertebrates recorded, with three species being represented: Hydropsyche angustipennis [Curtis, 1834], H.contubernalis [McLachlan, 1865] and H. pellucidula [Curtis, 1834]. H.contubernalis was the most abundant, comprising $71 \%$ of all hydropsychids, followed by H. pellucidula (12\%) and H. angustipennis (10\%). Dissection of the preserved enumeration trays indicated that retreats were constructed by tying together approximately six to seven clasts in the $4-6 \mathrm{~mm}$ trays, whereas, in the $6-8 \mathrm{~mm}$ colonisation trays, retreats were predominately constructed from only two or three clasts. Caddisfly nets were mainly found anchored to coarser particles or to the edges of the tray (Figure 5). A greater abundance of nets was found in the 6-8 mm trays, but nets were less common than retreats in all trays. 


\section{Evidence of other conditioning processes}

No evidence of macroinvertebrate colonisation was found in the conditioned trays (those covered in netting whilst in the field). However, both the field-conditioned and the colonised trays were affected by other natural conditioning processes that may have affected the entrainment thresholds of the fine gravels.

First, the discharge during field deployment induced bedload within the riffle. Sediment mobility was evidenced by the deposition of thin, superficial patches of fine sediment (predominantly medium-coarse sand) in colonised trays as well as the occasional larger clast (Figure 1). Sediment in the trays underwent low-flow reworking that may have increased grain stability (cf. Carling et al., 1992). In addition, some test grains were eroded from the trays (Figure 1) and there was minor scouring, as described above. In addition, from an initially random fabric, the test gravels became bedded down, such that the grains interlocked and presented a more compact surface, without conspicuously proud grains.

Second, patches of algae (biofilms) grew on the surface clasts, developing in association with the fine sediment deposited in the trays. There is a lack of clear information regarding the impact of bioflims on the entrainment of non-cohesive sediments in riverine settings. However, they are known to influence the stability of cohesive sediments (Gerbersdorf et al., 2008) and it is probable, therefore, that they increased stability via envelopment and agglutinisation of individual grains (Heinzelmann and Wallisch, 1991; Naylor and Viles, 2002).

The changes in grain size characteristics in the field-deployed trays requires further consideration in the context of the impacts of those changes on the subsequent experimental treatments. That fine sediment was added to most trays is of little consequence because the 
thin patches of sand were removed at low flow stage during entrainment tests in the flume. However, the deposition of larger particles of up to $22 \mathrm{~mm}$ was restricted to the colonised trays because the netting excluded them from the conditioned trays. We did not remove these clasts prior to the entrainment tests because of concern that this might disrupt silk bonds and destabilise the test grains. However, we were careful to observe that there were no obvious effects on entrainment during the experimental runs. This is likely to be because these clasts were rare (between 4 and 10 particles, representing 3 to $6 \%$ of the surface area). We were able to estimate the likely changes in grain size within the colonised trays by measuring those that occurred within the twelve enumeration trays, where postdeployment sieve analysis provided volume-by-weight grain-size distributions. The original test gravels dominated the final content, constituting an average of $82 \%$ (standard deviation $2 \%, n=12$ ); the percentage of imported coarser grains was approximately $10 \%$ (Table 1).

\section{Critical entrainment shear stresses}

Greater shear stresses were required to entrain fine gravel of both sediment sizes from the colonised trays than from both the uncolonised, conditioned trays and the laboratory trays (Figure 2). The critical shear stress for entrainment of 4-6 mm gravels from colonised trays was $35 \%$ greater than that for conditioned trays and 38\% greater than that required to entrain grains within the laboratory trays (Figure 2a). The equivalent figures for $6-8 \mathrm{~mm}$ gravels were $23 \%$ and $31 \%$, respectively (Figure $2 b$ ). The difference in critical entrainment stress between colonised and conditioned trays was significant for both 4-6 mm ( $\mathrm{t}=8.186$, $\mathrm{p}=0.000, \mathrm{n}=6)$ and $6-8 \mathrm{~mm}$ sediments $(\mathrm{t}=6.027, \mathrm{p}=0.002, \mathrm{n}=6)$. 
Interestingly, the difference in critical shear stress between the conditioned and laboratory trays was not significant for either the $4-6 \mathrm{~mm}(\mathrm{t}=1.206, \mathrm{p}=0.282, \mathrm{n}=6)$ or $6-8 \mathrm{~mm}(\mathrm{t}=$ 1.801, $\mathrm{p}=0.132, \mathrm{n}=6$ ) test sediments (Figures 3a and 3b).

There was also no significant difference in the shear stress required to entrain 4-6 mm gravels from trays mimicking scour and the laboratory trays $(t=-0.248, p=0.814, n=6)$, suggesting that scour of some colonised trays is unlikely to have affected measured entrainment stresses. This result is supported by the observation that entrainment thresholds were very consistent between colonised trays of 4-6 mm gravel despite varying amounts of scour (of between 0 and $0.01 \mathrm{~m}$; Figure 2).

\section{Shields parameter}

The Shields parameter was calculated so that comparisons could be drawn between the two grain-size fractions when determining if hydropsychid silk preferentially stabilises the finer gravel fraction (4-6mm). A two-way ANOVA shows that differences in the mean Shields parameter between tray treatments were significant $(\mathrm{F}=88.969, \mathrm{p}=<0.001)$, while Tukey's post-hoc multiple comparison indicates that the colonised trays were significantly different from the other treatments $(\mathrm{p}=<0.001)$. There was not, however, a significant difference in the Shields parameter between the two grain-sizes $(F=0.954, p=0.336)$ and no significant interaction between the two factors (treatment and grain size) occurred $(\mathrm{F}=$ $1.870, \mathrm{p}=0.172$ ). This suggests that $4-6 \mathrm{~mm}$ gravels were stabilised to a similar degree as corresponding 6-8 mm gravel by conditioning and colonisation processes (Figure 4). 


\section{Discussion}

Fine gravel in the colonised trays required significantly higher forces before entrainment than either field conditioned but uncolonised or unconditioned laboratory gravels. Our results lead us, therefore, to accept hypothesis 1 and to conclude that the presence of Hydropsychidae caddisflies increases the critical shear stress. Evidence of Hydropsychidae larvae silk was found in all enumeration trays and was observed to be an effective stabilising agent both in the field and flume. The threshold of incipient motion for the sediment in the conditioned trays was not significantly different from that of sediment in the laboratory trays that were not subject to river conditioning. Therefore, we reject hypothesis 2 and conclude that the sediment reworking and biofilm development observed in the field had no measurable effect on the stability of the fine gravel under test. Counter to hypothesis 3 , the $4-6$ and 6-8 mm gravels were stabilised to a similar degree and we conclude that, for this marginal but significant difference in grain size, there is no demonstrable impact of Hydropsychidae caddisflies: both grain-size fractions experienced similar increases in the dimensionless threshold of incipient motion.

In general, these results support the findings of earlier work (Statzner et al., 1999; Cardinale et al., 2004), but they also extend that work in two important ways: we have established elevated thresholds of incipient motion for fine gravels that have been colonised at natural densities and under natural stream conditions; and we have measured caddisfly impact relative to both laboratory and field-conditioned controls. 


\section{Natural colonisation densities and the impact of Hydropsychidae as ecosystem engineers}

Likely controls on the importance of ecosystem engineering include biological interactions such as competition and predation (Statzner \& Peltret, 2006; and Statzner \& Sagnes, 2008) as well as the body size and behaviour of individuals (Moore, 2006). Although we have not examined such additive effects (cf. Statzner and Sagnes, 2008), the use of natural field sites at least provided scope for unfettered interaction between organisms, not least in terms of natural colonisation densities: Hydropsychidae larvae numbers presumably reflect local competition and other biological and physical factors. In their flume experiment, Cardinale et al. (2004) also found that the presence of these organisms increased bed-grain stability, but their seeded densities were much higher than those in the current study. At their "low" hydropsychid density (904 larvae $\mathrm{m}^{-2}$ remaining after experiment), the substrate required a $10 \%$ increase in velocity before entrainment. At their highest density (2542 larvae $\mathrm{m}^{-2}$ remaining after the experiment) this increase rose to 30\%. Our colonisation densities were only 113-564 larvae $\mathrm{m}^{-2}$ for 4-6 mm sediment and 489-1053 larvae $\mathrm{m}^{-2}$ for 6-8 mm sediment, but the impact on entrainment was still highly significant. This implies that high densities of hydropsychids are not required to increase the threshold of incipient motion.

That low densities of caddisflies are able to reduce grain entrainment from relatively unstable patches of fine gravel is interesting when it is considered that the highest densities of these larvae are typically found on large, stable particles. Stable locations with high densities are relatively safe but competition for food, space and other resources is relatively high. It may be the case that, on finer-grained patches, the engineering activities of these larvae are sufficient to substantially offset the apparent disadvantage of living on an 
unstable substrate and, indeed, offer comparable benefit overall, given the greater abundance of food and individual space relative to more stable, but densely occupied sites.

In any case, the stabilisation of these otherwise unattractive locations by relatively low numbers of larvae illustrates the fundamental importance of ecosystem engineering activity, i.e. the creation of a habitat that would not otherwise be available (cf. Gutiérrez et al., 2003). The presence of caddisfly silk would not be significant on substrates which are already stable enough to support high densities of macroinvertebrates. However, the stabilisation of bed grains benefits the sedentary lifestyle of this organism and other macroinvertebrates.

\section{The relative importance of Hydropsychidae larvae and other conditioning factors}

The similarity of the entrainment stresses in the field-conditioned but uncolonised and laboratory trays is interesting and unexpected. It implies that exposure to several potentially important stabilising mechanisms (other than Hydropsychidae larvae silk) had no significant effects on the trays of sediment deployed in the river. These include: (1) exposure of the unstructured gravels to twenty-one days of natural flows with daily discharges that varied between 2.7 and $7.4 \mathrm{~m}^{3} \mathrm{~s}^{-1}$; and (2) the development of algal biofilm. Many studies have argued that, after a flood event when the bed is relatively loose, lowflow conditions organise the substrate by moving vulnerable grains and arranging the surface particles into a more flow resistant pattern (e.g. Carling et al., 1992; Wilcock \& McArdell, 1993). Although low-flow reworking of sediment was observed in this study, the 
uniform size of each fine gravel used probably limited the impact on grain stability of any reworking. It is possible that experiments utilising larger ranges of grain-size would have let us find a larger difference between entrainment stresses between field-conditioned and laboratory trays.

Biofilm development was also found to have no impact in this study. There is no evidence that by covering and by bonding together surface grains, biofilm offer protection from the flow and increased entrainment stresses. There is some evidence that biofilms are not effective in stabilising grains greater than $2 \mathrm{~mm}$ in diameter (Heinzelmann, 1992; Statzner, 1999) and the muddy biofilm present on our fine-gravels was quickly eroded in the flume at low-flow stages, leaving the underlying grains exposed to the flow.

\section{Grain-size effects and the role of silken retreats versus nets}

The experimental flow-channel study of Cardinale et al. (2004) found that Hydropsychidae larvae stabilised finer ( 2 and $4 \mathrm{~mm}$ ) sediment fractions to a greater extent than coarser fractions $(8 \mathrm{~mm})$. In this study, both fractions were stabilised to a similar degree, although the Shields parameter was slightly greater for the finer gravels. Cardinale et al. (2004) hypothesised that silk nets were the main stabilising agent. In the present study, although the 4-6 mm sediment had a lower density of Hydropsychidae larvae than the 6-8 $\mathrm{mm}$ sediment, the 4-6 mm enumeration trays had more caddisfly retreats because there were more interstices than found in the $6-8 \mathrm{~mm}$ observation trays. These retreats were observed to be effective stabilising agents both in the flume and in the field: when trays were removed from the river, large quantities of adjacent substrate remained attached to the tray edges (Figure 5). The apparent importance of retreats, rather than nets, in the River Soar contrasts with the observations of Cardinale et al. (2004). However, there is evidence that 
the construction of nets and/or retreats may reflect local hydraulic conditions and may be influenced by competition between individuals for space and food resources (Statzner \& Bretschko, 1998). This may help explain the contrasting observations, because the naturally colonised larvae densities in our study (113-1053 larvae $\mathrm{m}^{-2}$ ) are substantially lower than the seeded densities (904-2542 larvae $\mathrm{m}^{-2}$ remaining after the experiment) in the study of Cardinale et al. (2004).

\section{Scaling-up the local geomorphological effect of caddisfly larvae}

It is interesting to consider the large-scale, geomorphological implications of ecosystem engineering activities. Moore (2006) estimated that, in small Alaskan streams, spawning sockeye salmon (Oncorhynchus nerka) collectively disturb in excess of $30 \%$ of the substrate surface every year and Gottesfeld et al. (2004) found that cumulative sockeye effects had the same relative importance for bedload transport as some flood events.

Here, the geomorphological implications of fine-gravel stabilisation by Hydropsychidae larvae are difficult to gauge. In particular, the spatial extent and seasonality of their influence are currently unquantified and we have no systematic understanding of the limits of their impact in terms of both the flow magnitudes and the grain sizes above which their effect disappears. Without such information it is only possible to speculate about their cumulative impact. It is likely that their effect is spatially patchy at the local level as a function of other abiotic and biotic controls on the distribution of the larvae and because only relatively fine sediment fractions are likely to be strongly affected. Similarly, it seems unlikely that they play a role during large flood events that mobilise a large proportion of 
the river-bed material. However, the cumulative impact of hydropsychid caddisflies on the redistribution of fine-grained sediments between large floods could be both widespread and persistent because they are one of the most diverse families of lotic invertebrates worldwide (Wallace \& Merritt, 1980) and developing larvae of Hydropsychidae are present within riverine systems all year round in the UK (Boon, 1979; Edington and Hildrew, 1995).

Notwithstanding our inability to quantify the impact of hydropsychid caddisfly silk on sediment flux, we can draw attention to the reminder brought by Leopold (1992) and further developed by Lisle (1995) that bedload is often dominated by sand in many river

environments. Here, an increase in entrainment threshold due to hydropsychid caddisfly silk of c. $30 \%$ might be reducing fine-grained bedload yield by a significant amount. Indeed, the impact of such a restraining mechanism might add a new dimension to the findings of Reid et al. (1985, 1986) that entrainment and 'distrainment' thresholds differ significantly during the passage of a flood wave, a phenomenon they attributed to the binding effects of interstitial fines in the absence of knowledge of ecosystem engineering by invertebrates. Looked at the other way, an absence of the effects of hydropsychid caddisfly silk might lead to larger flux of fine-grained bedload and have considerable cumulative consequences for nuisances such as reservoir sedimentation.

\section{Conclusions}

The combined field and flume experiments described here support the findings of earlier work in this area (Statzner et al., 1999; Cardinale et al., 2004) and extend that work in two important ways. First, we have established that there are elevated thresholds of incipient 
motion for fine gravels that are colonised in a natural river setting as distinct from gravels seeded with larvae in small, experimental channels. The colonisation densities that were observed are much lower than in flume experiments and are the product of a suite of abiotic and biotic processes that influence colonisation in natural settings. The strong impact of the Hydropsychidae caddisflies on entrainment (for example, an increase in critical shear stress of $35 \%$ for $4-6 \mathrm{~mm}$ fine gravels) indicates that they might have a substantial effect on finegrained bedload flux in natural settings. Second, we have measured the caddisfly effect alongside both field-conditioned, uncolonised and unconditioned, uncolonised laboratory controls. This has allowed us to assess the importance of the caddisfly relative to the combined impact of other factors that condition the bed and may influence particle entrainment. Somewhat surprisingly, we found that in-stream conditioning processes, such as biofilm development and the reworking of grains by low flows, had no measurable impact on incipient motion of fine gravels. Consequently, we conclude that these larvae are locally very important for stabilising fine-grained patches. Ecologically, this benefits both the Hydropsychidae larvae and other sedentary macroinvertebrates by creating habitats that would not otherwise be available. This makes these organisms important ecosystem engineers. The cumulative impact of silk-spinning caddisflies at larger, geomorphological scales is difficult to quantify. However, given their global distribution and the staggered nature of their life histories it is likely that they influence the downstream redistribution of fine sediments much of the time and in many rivers worldwide. 


\section{References}

Alstad DN. 1987a. Particle size, resource concentration and the distribution of net-spinning caddisflies. Oecologia 71: 525-531.

Alstad DN. 1987b. A capture-rate model of net-spinning caddisfly communities. Oecologia 71: $532-536$.

Boon PJ. 1979. Studies on the spatial and temporal distribution of larval Hydropsychidae in the North Tyne river system (Northern England). Archiv fur Hydrobiologie 85 : 336-359.

Brown SA, Ruxton GD, Pickup RW, Humphries S. 2005. Seston capture by Hydropsyche siltalai and the accuracy of capture efficiency estimates. Freshwater Biology 50 : 113-126.

Buffin-Bélanger T, Rice S, Reid I, Lancaster J. 2006. Spatial heterogeneity of near-bed hydraulics above a patch of river gravel. Water Resources Research 42 : W04413, doi:10.1029/2005WR004070.

Buffington JM, Montgomery DR. 1997. A systematic analysis of eight decades of incipient motion studies, with special reference to gravel-bedded rivers. Water Resources Research 33 : 1993-2029.

Butler DR. 1995. Zoogeomorphology: animals as geomorphic agents. Cambridge University Press: Cambridge.

Butler DR, Malanson GP. 2005. The geomorphic influences of beaver dams and failures of beaver dams. Geomorphology 71 : 48-60. 
Cardinale BJ, Gelmann ER, Palmer MA. 2004. Net spinning caddisflies as stream ecosystem engineers: the influence of Hydropsyche on benthic substrate stability. Functional Ecology 18 : 381-387.

Cardinale, BJ, Palmer MA, Swan CM, Brook S, Poff NL. 2002 The influence of substrate heterogeneity on biofilm metabolism in a stream ecosystem. Ecology 83 : 412-422.

Carling PA, Kelsey A, Glaister MS. 1992. Effect of bed roughness, particle shape and orientation on initial motion criteria. In Dynamics of Gravel-Bed Rivers , Billi P, Hey RD, Thorne CR, Tacconi P (eds) John Wiley \& Sons: Chichester; 23-38.

Cotton JA, Wharton G, Bass JAB, Heppell CM, Wotton RS. 2006. The effects of seasonal changes to in-stream vegetation cover on patterns of flow and accumulation of sediment. Geomorphology 77 : 320-334.

Dietrich WE, Perron E. 2006 The search for a topographic signature of life. Nature 439 : 411-418.

Edington JM, Hildrew AG. 1995. Caseless caddis larvae of the British Isles: a key with ecological notes. Freshwater Biological Association Scientific Publication No. 53: Cumbria.

Edler C, Georgian T. 2004. Field measurements of particle-capture efficiency and size selection by caddis fly nets and larvae. Journal of the North American Benthological Society 23 : 756-770. 
Fenton JD, Abbott JE. 1977. Initial movement of grains on a stream bed: the effect of relative protrusion. Proceedings of the Royal Society of London 352 : 523-537.

Flecker AS. 1996. Ecosystem engineering by a dominant detritivore in a diverse tropical stream. Ecology 77 : 1845-1854.

Garcia C, Cohen H, Reid I, Rovira A, Úbeda X, Laronne JB. 2007. Processes of initiation of motion leading to bedload transport in gravel-bed rivers. Geophysical Research Letters 34: L06403, doi:10.1029/2006GL028865.

Gerbersdorf SU, Jancke T, Westrich B and Patterson DM. 2008. Microbial stabilisation of riverine sediments by extracellular polymeric substances. Geobiology 6 : 57-69.

Gottesfeld AS, Hassan MA, Tunnicliffe JF, Poirier RW. 2004. Sediment dispersion in salmon spawning streams: the influence of floods and salmon redd construction. Journal of the American Water Resources Association 40 : 1071-1086.

Green JC. 2005. Velocity and turbulence distribution around lotic macrophytes. Aquatic Ecology 39 : 1-10.

Gurnell AM. 1998. The hydrogeomorphological effects of beaver dam-building activity. Progress in Physical Geography 22 : 167-189.

Gutiérrez JL, Jones CG, Strayer DL, Iribarne OO. (2003) Mollusks as ecosystem engineers: the role of shell production in aquatic habitats. Oikos 101 : 79-90.

Heinzelmann C, Wallisch S. 1991. Benthic settlement and bed erosion: a review. Journal of Hydraulic Research 29: 355-371. 
Heinzelmann C. 1992. Auswirkungen benthischer Diatomeenfilmeauf die Sohlenerosion in Fleissgewassern. PhD thesis, 153pp, Tech. Univ. Darmstadt, Germany (in German).

Jones CG, Lawton JH, Shachak M. 1994. Organisms as ecosystem engineers. Oikos 69 : 373-386.

Kondolf GM, Sale MJ, Wolman MG. 1993. Modification of fluvial gravel size by spawning salmonids. Water Resource Research 29 : 2265-2274.

Komar PD, Li Z. 1986. Pivoting analyses of the selective entrainment of sediments by shape and size with application to gravel thresholds. Sedimentology 33 : 425-436.

Lancaster J. 2000. Geometric scaling of microhabitat patches and their efficacy as refugia during disturbance. Journal of Animal Ecology 69 : 442-457.

Lancaster J, Hildrew AG (1993) Characterizing instream flow refugia. Canadian Journal of Fisheries and Aquatic Sciences 50 : 1663-1675.

Leopold LB. 1992. Sediment size that determines channel morphology. In Dynamics of Gravel-Bed Rivers , Billi P, Hey RD, Thorne CR, Tacconi P (eds) John Wiley \& Sons: Chichester; 297-307.

Lisle TE. 1995. Particle size variations between bed load and bed material in natural gravel bed channels. Water Resources Research 31: 1107-1108.

Mackay RJ. 1992. Colonisation by lotic macroinvertebrates: a review of processes and patterns. Canadian Journal of Fisheries and Aquatic Sciences 49 : 617-628. 
Mermillod-Blondin F, Gaudet J-P, Gerino M, Desrosiers G, Creuze des Chatelliers M. 2003. Influence of macroinvertebrates on physico-chemical and microbial processes in hyporheic sediments. Hydrological Processes 17 : 779-794.

Moore JW. 2006. Animal ecosystem engineers in streams. Bioscience 56 : 237-246.

Moore JW, Schindler DE, Scheuerell MD. 2004. Disturbance of freshwater habitats by anadromous salmon in Alaska. Oecologia 139 : 298-308.

Naylor LA, Viles HA. 2002. A new technique for evaluating short-term rates of coastal bioerosion and bioprotection. Geomorphology 47:31-44.

Neill CR, Yalin MS. 1969. Quantitative definition of beginning of bed movement. Journal of Hydraulic Engineering 95 : 585-587.

Newson MD. 1992. Geomorphic thresholds in gravel-bed rivers - refinement for an era of environmental change. In Dynamics of gravel-bed rivers , Billi P, Hey RD, Thorne CR, Tacconi P (eds). John Wiley \& Sons: Chichester; 3-20.

Nogaro G, Mermillod-Blondin F, Francois-Carcaillet F, Gaudet J-P, Lafont M, Gibert J. 2006. Invertebrate bioturbation can reduce the clogging of sediment: an experimental study using infiltration sediment columns. Freshwater Biology 51 : 1458-1473.

Paintal AS. 1971. Concept of critical shear stress in loose boundary open channels. Journal of Hydraulic Research 9 : 91-113. 
Parkyn SM, Rabeni CF, Collier KJ. 1997. Effects of crayfish (Paranephrops planifrons: Parastacidae) on in-stream processes and benthic faunas: a density manipulation experiment. New Zealand Journal of Marine and Freshwater Research 31 : 685-692.

Power ME. 1990. Resource enhancement by indirect effects of grazers: armored catfish, algae, and sediment. Ecology 71 : 897-904.

Pringle CM, Blake GA, Covich AP, Buzby KM, Finley A. 1993. Effects of omnivorous shrimp in a montane tropical stream: sediment removal, disturbance of sessile invertebrates and enhancement of understorey algal biomass. Oecologia 93 : 1-11.

Reid I, Frostick LE, Layman JT. 1985. The incidence and nature of bedload transport during flood flows in coarse-grained alluvial channels. Earth Surface Processes \& Landforms 10: 33-44.

Reid I, Frostick LE. 1986. Dynamics of bedload transport in Turkey Brook, a coarsegrained alluvial channel. Earth Surface Processes \& Landforms 11: 143-155.

Stallins LA. 2006. Geomorphology and ecology: unifying themes for complex systems in biogeomorphology. Geomorphology 77 : 297-216.

Statzner B, Arens MF, Champagne JY, Morel R, Herouin E. 1999. Silk producing stream insects and gravel erosion: significant biological effects on critical shear stress. Water Resource Research 35 : 3495-3506. 
Statzner B, Bretschko G. 1998. Net-building of a caddis fly (Hydropsyche siltalai) in a French stream: relations with larval density and physical conditions. Archiv für Hydrobiologie 144 : 87-102.

Statzner B, Peltret O. 2006. Assessing potential abiotic and biotic complications of crayfish-induced gravel transport in experimental streams. Geomorphology 74 : 245-256.

Statzner B, Peltret O, Tomanova S. 2003a. Crayfish as geomorphic agents and ecosystem engineers: effect of a biomass gradient on baseflow and flood-induced transport of gravel and sand in experimental streams. Freshwater Biology 48 : 147-163.

Statzner B, Sagnes P. 2008. Crayfish and fish as bioturbators of streambed sediments: assessing the joint effects of species with different mechanistic abilities. Geomorphology 93 : 267-287.

Statzner B, Sagnes P, Champagne J-Y, Viboud S. 2003b. Contribution of benthic fish to the patch dynamics of gravel and sand transport in streams. Water Resource Research 39: 1309 doi:10.1029/2003WR002270.

Takao A, Negishi JN, Nunokawa M, Gomi T, Nakahara O. 2006. Potential influences of a net-spinning caddisfly (Trichoptera: Stenopsyche marmorata) on stream substratum stability in heterogeneous field environments. Journal of the North American Benthological Society 25 : 545-555.

Thomson MT, Thomas SA, Minshall WG, Newbold DJ, Cushing CE. 2001. The influence of filter-feeding benthic macroinvertebrates on the transport and deposition of particulate organic matter and diatoms in two streams. Limnology and Oceanography 46 : 1091-1099. 
Trimble SW, Mendel AC. 1995. The cow as a geomorphic agent - a critical review. Geomorphology 13: 233-253.

Viles H. 1988. Biogeomorphology. Basil Blackwell: Oxford.

Wallace J, Merritt R. 1980. Filter-feeding ecology of aquatic insects. Annual Review of Entomology 25: 103-133.

Wharton G, Cotton JA, Wotton RS, Heppell CM, Trimmer M, Sanders IA, Warren LL. 2006. Macrophytes and suspension-feeding invertebrates modify flows and fine sediments in the Frome and Piddle catchments, Dorset. Journal of Hydrology 330 : 171-184.

Wilcock PR. 1988. Methods for estimating the critical shear stress of individual fractions in a mixed-size sediment. Water Resources Research 24: 1127-1135.

Wilcock PR, McArdell BW. 1993. Surface-based fractional transport rates: mobilization thresholds and partial transport of a sand-gravel sediment. Water Resources Research 29: $1297-1312$.

Winterbottom JH, Orton SE, Hildrew AG, Lancaster J. 1997. Field experiments on flow refugia in streams. Freshwater Biology 37: 569-580.

Zanetell BA, Peckarsky B. 1996. Stoneflies as ecological engineers - hungry predators reduce fine sediments in stream beds. Freshwater Biology 36: 569-577. 
Table 1. Percentage weights of material in observation trays in relation to the original size fraction

\begin{tabular}{|c|c|c|c|c|}
\hline Tray & Grain size & $\%$ finer & $\%$ original & \% coarser \\
\hline 1 & 4-6 mm & 10.1 & 84.7 & 5.2 \\
\hline 2 & 4-6 mm & 8.9 & 84.1 & 7.1 \\
\hline 3 & 4-6 mm & 7.0 & 83.8 & 9.2 \\
\hline 4 & 4-6 mm & 8.4 & 80.0 & 11.7 \\
\hline 5 & 4-6 mm & 8.2 & 79.0 & 12.8 \\
\hline \multirow[t]{2}{*}{6} & $4-6 \mathrm{~mm}$ & 7.5 & 82.4 & 10.1 \\
\hline & Mean & 8.3 & 82.3 & 9.3 \\
\hline 1 & $6-8 \mathrm{~mm}$ & 6.5 & 83.1 & 10.4 \\
\hline 2 & $6-8 \mathrm{~mm}$ & 8.6 & 80.5 & 10.8 \\
\hline 3 & $6-8 \mathrm{~mm}$ & 7.9 & 82.8 & 9.2 \\
\hline 4 & $6-8 \mathrm{~mm}$ & 8.9 & 82.0 & 9.1 \\
\hline 5 & $6-8 \mathrm{~mm}$ & 9.4 & 80.0 & 10.6 \\
\hline \multirow[t]{2}{*}{6} & $6-8 \mathrm{~mm}$ & 8.1 & 79.6 & 12.4 \\
\hline & Mean & 8.2 & 81.3 & 10.4 \\
\hline
\end{tabular}




\section{List of Figures}

Figure 1. Two experimental trays in situ at the field site on the River Soar. Flow is from top to bottom. Minor reworking of sediment is apparent in the erosion of some grains from and the deposition of others within the trays.

Figure 2. Critical shear stresses at entrainment for colonised (circles), conditioned (squares) and laboratory (triangles) trays containing (a) 4-6 mm gravel and (b) 6-8 mm gravel.

Figure 3. Shear stress $\left(\mathrm{N} \mathrm{m}^{-2}\right)$ for colonised, conditioned and laboratory treatments. Mean \pm 2 standard errors for: (a) 4-6 mm and (b) 6-8 mm sediments. Significant results of paired two-way t-tests $(\mathrm{p}<0.005)$ are highlighted.

Figure 4. Shields parameter (mean \pm 2 standard errors) for entrainment of (a) 4-6 mm gravels and (b) 6-8 mm gravels under colonised (circles), conditioned (squares) and laboratory (triangles) treatments.

Figure 5. Outside edge of an experimental tray recently recovered from the river, showing the adhesive effects of Hydropsychidae silk. The various grains (from 6 to 22 $\mathrm{mm}$ ) are being held together and are hanging from the tray edge unsupported except for the silk that binds them together. A silk net is apparent on the top right corner of the largest particle and several retreats, constructed using strands of silk which are visible, are evident to the left of the large particle. The total height of the tray is $50 \mathrm{~mm}$. 


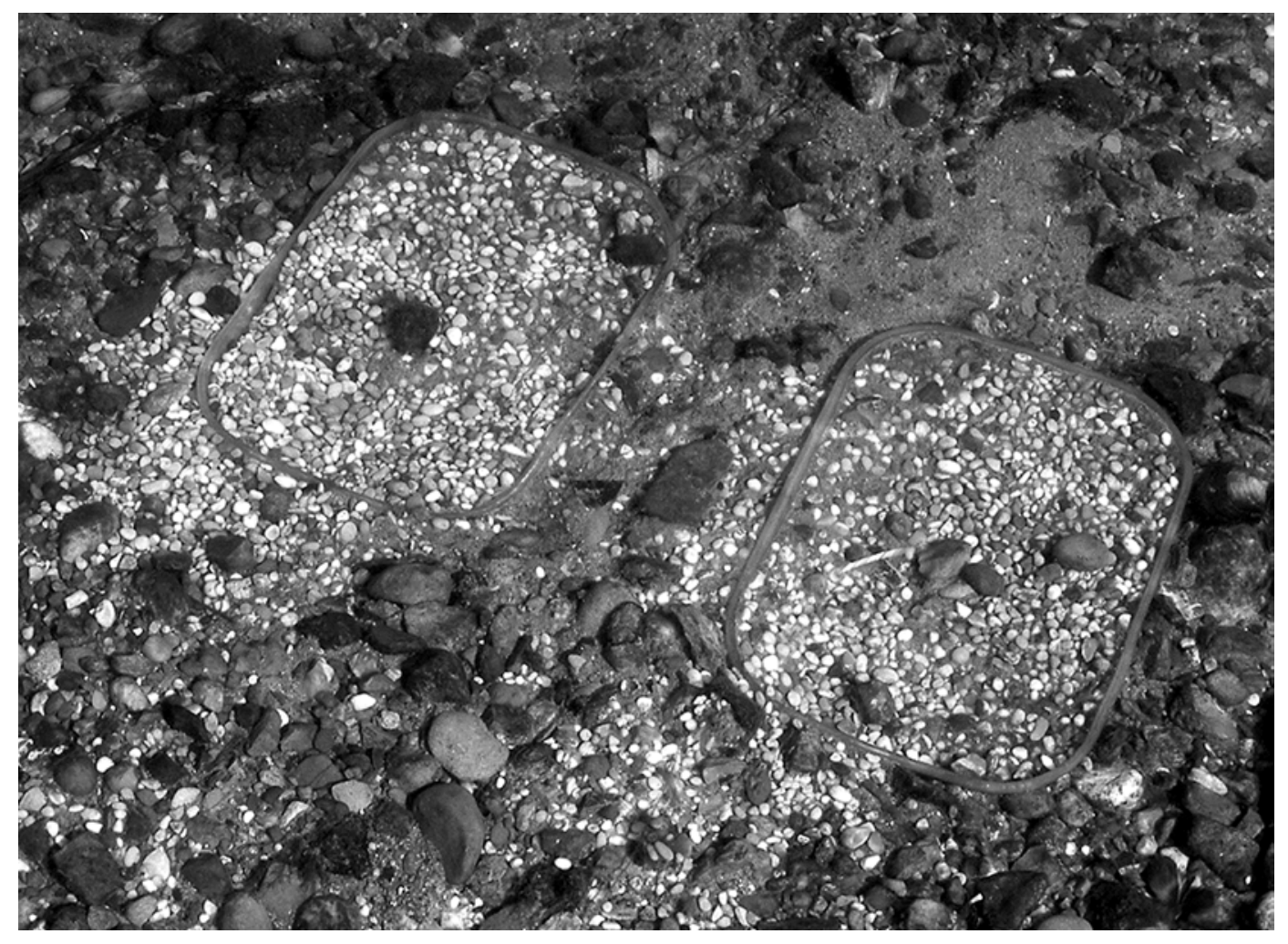

Figure 1 

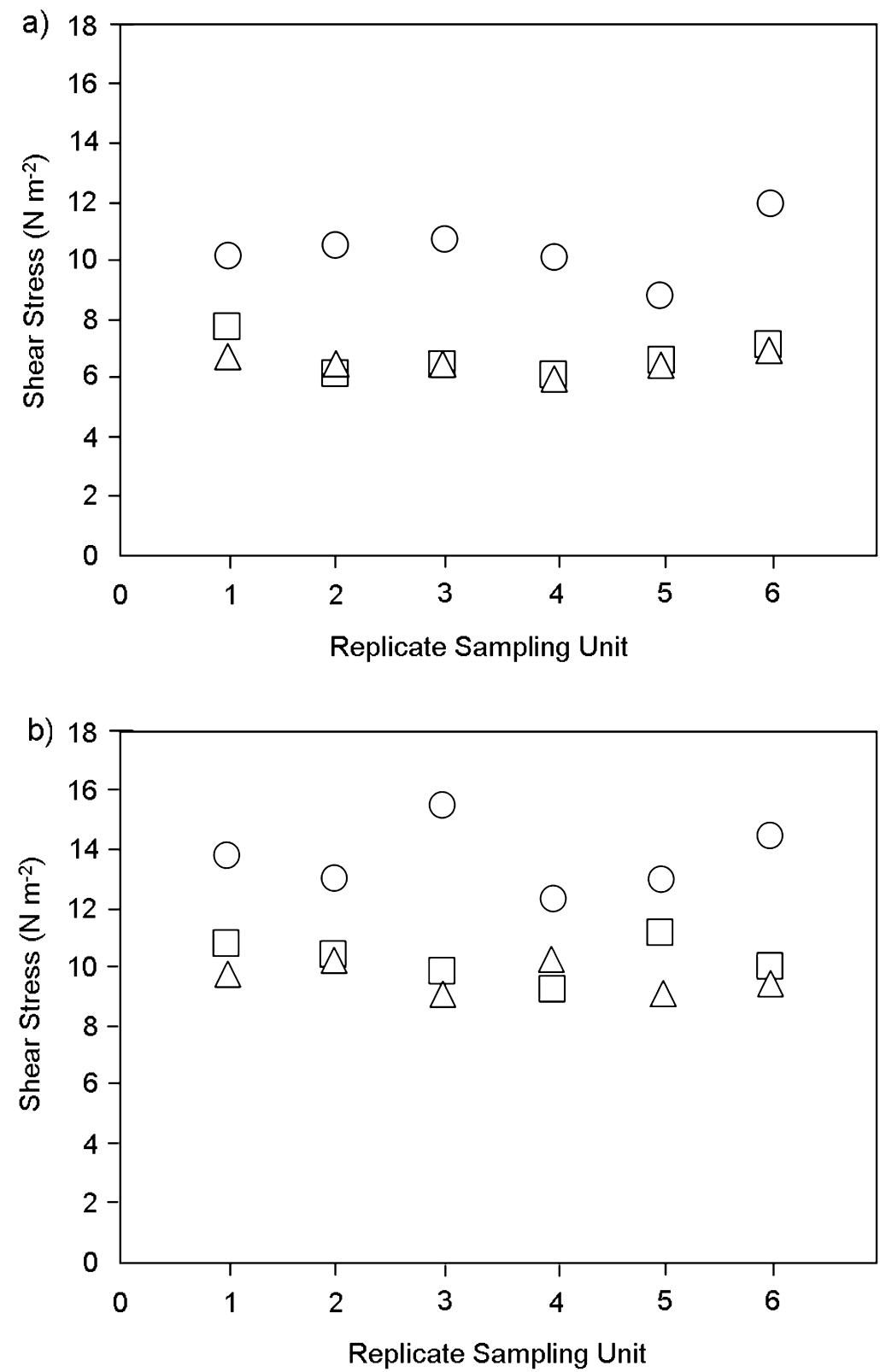

Figure 2 

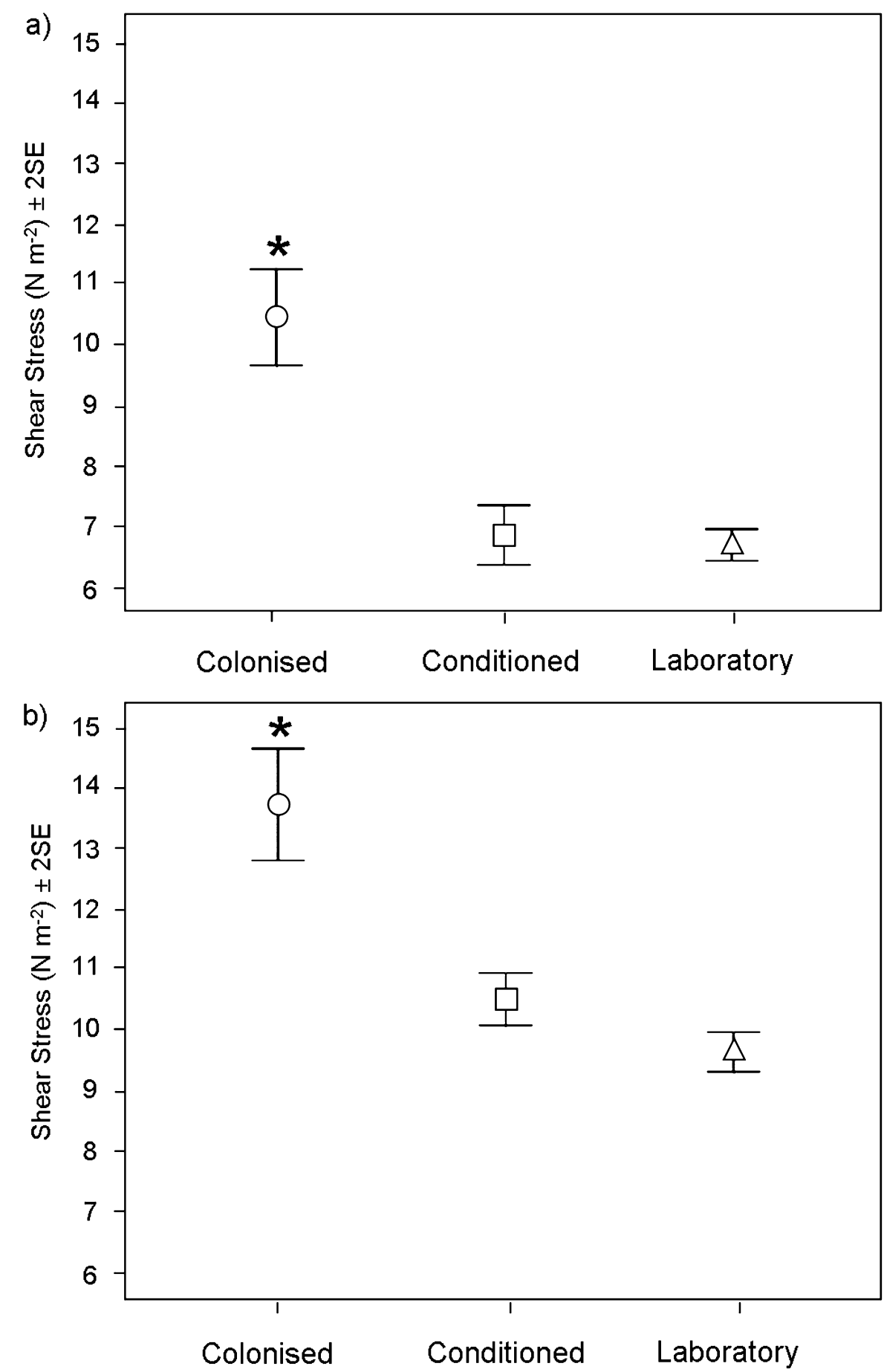

Figure 3 


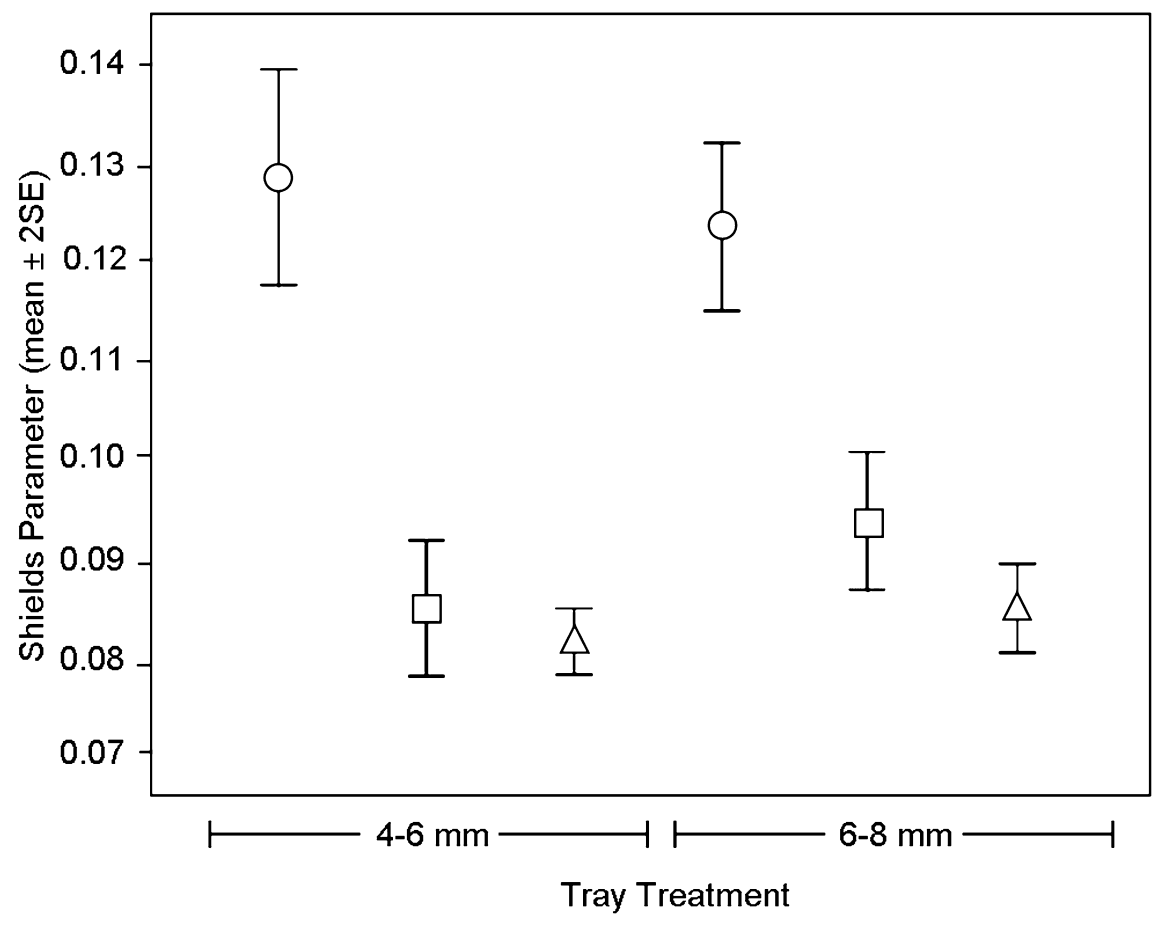

Figure 4 


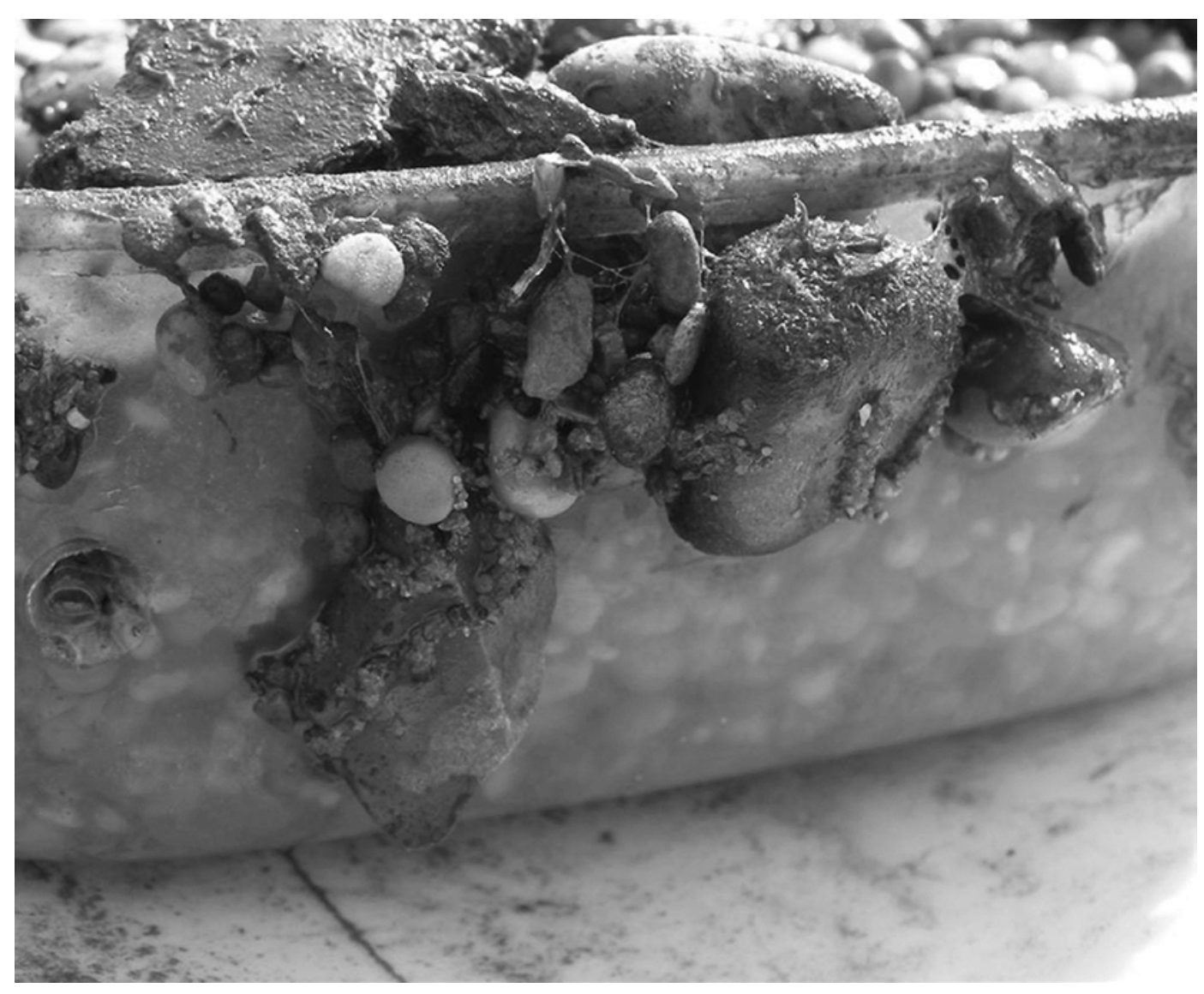

Figure 5 